Article

\title{
Bataille and Nietzsche on the Limits and Ambiguities of Sovereignty and Power ${ }^{1}$
}

George Papandreopoulos

\begin{abstract}
This paper will argue that both Bataille and Nietzsche embrace a rather idiosyncratic understanding of sovereignty (Bataille) and power (Nietzsche), according to which the sovereign moment is to be identified with a moment of profound loss. For both thinkers, sovereignty and power do not stand alone but are absolutely dependent on forces which threaten their integrity at every moment. For both, the ultimate powerlessness of power, or the loss of sovereignty, does not constitute weakness but precisely the opposite, strength and vitality. Nietzsche occupies himself with the problem of power through his examination of ancient agon, where he organises the limitations of power; through his occupation with the Will to Power, where he constructs an ontology of power; and finally through his meditations on the thought of the return, where the power of time manifests itself in the sovereignty of a moment which has liberated itself from the demands of various cultural and social power structures which have produced the human of the Christian Western civilisation: a human solely occupied with productions and results. Ultimately, this paper aims to elucidate that Bataille's sovereignty and Nietzsche's power win nothing specific; but that their sovereignty lies in their resistance to the Western cultural model of understanding life through the optics of productions, wins, and results.
\end{abstract}

Keywords: sovereignty, power, unproduction, time

${ }^{1}$ I would like to thank Professor Douglas Burnham for inviting me to present a first draft of this paper at Staffordshire University and to his students for their valuable comments. I would also like to thank the anonymous editor of KRITIKE for his much helpful comments.

(c) 2016 George Papandreopoulos

http://www.kritike.org/journal/issue 18/papandreopoulos june2016.pdf

ISSN 1908-7330 


\author{
As you see, some defeats can be transformed into \\ victorious calamities \\ - António Lobo Antunes, The Land at the End of the World
}

\title{
‘Sovereignty' in Bataille
}

Tn his magnum opus The Accursed Share (1949), Georges Bataille develops a very interesting and fruitful concept, that of 'sovereignty.' Sovereignty describes the process whereby human existence realigns itself to the wasteful movement of the cosmos. ${ }^{2}$ Sovereignty is fundamentally directed against the world of 'projects,' the world of utilitarian calculations and capitalist production. It is the necessary outcome of 'general economics,' the economic structure of societies around the notions of expenditure and (economic) waste, and the completion of the type of human that 'general economics' produces: a squanderer dedicated to nothing but the (unintentional) disruption of life on earth as a productive enterprise. It is in and through his loss (the squandered loses everything including himself), though, that the sovereign individual achieves the summit of an experience that overcomes the petty calculations of the productive-human machines. It is because he wishes nothing more than the immediate enjoyment of the experience of his existence (like the notorious child-murderer Gilles de Rais), beyond the demands posed on him by institutions and ideologies, that the sovereign individual becomes the master, the sovereign of his existence. However, this is not to confuse sovereignty with idleness, however spectacular and charming this idleness could be. Like 'inner experience' sovereignty also describes a process, which nevertheless culminates in the experience of the dissolution of all processes. It is a 'negative project,' a project that abolishes all projects. ${ }^{3}$ Thus the sovereign has to achieve his sovereignty ${ }^{4}$ and he has then to implicate himself in a project to oppose all earthly projects.

\section{Hegelian Beginnings}

Bataille's exposition of the notion of sovereignty owes a lot to the profound influence of the (anthropological) reading of Hegel's Phenomenology of the Spirit (1807) by Alexander Kojeve. In the much-discussed chapter on 'Lordship and Bondage,' self-consciousness, after having duplicated itself,

\footnotetext{
${ }^{2}$ For Bataille the real economic problem of humanity lies not in a lack of resources, but rather in the excess of energy radiating from the sun. It is not that we do not have enough; the problem is that we have too much!

${ }^{3}$ Georges Bataille, Inner Experience, trans. by Stuart Kendall (Albany: SUNY Press, 2014), 29.

${ }^{4} \mathrm{He}$ thus differs from the royal sovereigns who 'find,' or are offered, their sovereignty.

(c) 2016 George Papandreopoulos

http://www.kritike.org/journal/issue 18/papandreopoulos june2016.pdf

ISSN 1908-7330

(c) BY-NC-ND
} 
understands the need to be recognised by another self-consciousness which is not going to be a mirror picture of itself but a free, independent selfconsciousness, since the fundamental presupposition of recognition is to set the 'other' free, or else recognition is reduced to brute coercion. One is only recognised by another which is wholly other and both self-consciousnesses must mutually recognise each other which means to accept the other as free. ${ }^{5}$ This is of course the final and much desired state of recognition, but before that a battle has to take place between the two self-consciousnesses, a battle where the opposing self-consciousnesses have to prove that they are not attached to any particularity whatsoever, including life itself. They both have to prove that they are completely and utterly free, which means they have no commitments, no attachments to anything external to their own existence. A self-consciousness which is attached to life is a self-consciousness which is attached to something external to its own self. Hegel thinks that a self (consciousness) is not characterised by its commitment to life, but by its commitment to its independence; therefore, life (as a biological existence) is treated as something accidental or in any case as something of no particular importance to self-consciousness's development. In Hegel's words:

... it is only through staking one's life that freedom is won; only thus is it proved that for self-consciousness, its essential being is not [just] being ... but rather there is nothing present in it which could not be regarded as a vanishing moment, that it is pure being-for-self. ${ }^{6}$

Or, as Alexandre Kojeve puts it in his own anthropological terms: “... to be for one self, or to be a man, is not to be bound to any determinate existence, not to be bound to the universal isolated-particularity of existence as such, not to be bound to life."7 The problem arising from the struggle for recognition is obvious. Both self-consciousnesses want their freedom, i.e. they wish to express their contempt for every attachment, including 'my' life and 'your' life. But however much each wishes to be recognised by the other, if the outcome of the battle is to be the death of one or the other of the parties involved, then recognition cannot take place. Self-consciousness finds itself in the paradoxical condition of being compelled to preserve the other in life in

${ }^{5}$ G.W.F. Hegel, Phenomenology of Spirit, trans. by A. V. Miller (Oxford and New York: Oxford University Press, 1977), §184. See also Alexandre Kojeve, Introduction to the Reading of Hegel: Lectures on the Phenomenology of Spirit, trans. by James H. Nichols, Jr. (Ithaca and London: Cornell University Press, 1980), 36-44.

${ }^{6}$ Hegel, Phenomenology of Spirit, §187.

${ }^{7}$ Kojeve, Introduction to the Reading of Hegel, 12.

(C) 2016 George Papandreopoulos http://www.kritike.org/journal/issue 18/papandreopoulos june2016.pdf ISSN 1908-7330 
order to render 'him' able to be participant in a relation where both members have to recognise each other.

Thus, the precondition of the mastery of the master becomes for Hegel the willingness to dissociate self-consciousness from the 'animal need' for biological preservation. Bataille agrees that "to struggle without having the satisfaction of animal needs as an object is above all in itself sovereign; it expresses a sovereignty." 8 Bataille speaks, then, for a mastery which is master-full only insofar as it is master-less, only insofar as it "lets itself go." But the less of mastery rather than expressing, what Nietzsche has called "passive Nihilism," 9 the state of the decline of power that stands "at the door" of modernity, rather expresses Nietzsche's second suggestion regarding nihilism, which he calls "activer Nihilism,"10 and refers to a "violent force of destruction" [gewaltthätige Kraft der Zestörung]. ${ }^{11}$ This force is able to bring the process of the taming of the human animal ${ }^{12}$ to its ultimate consequences and thus to the ultimate and much-desired agon between the healthy and the unhealthy forces in man. Bataille understands that Nietzsche's activer Nihilism is taken over by Hegelian negativity and that negativity is made to correspond, through Kojeve, to action ${ }^{13}$ which opposes the world of animal desire and thus inaugurates man's participation in human history. Bataille never tires of repeating this Kojevean lesson: "Action is Negativity and Negativity, Action."14 The master-less-ness of mastery, then, rather than indicating a vacuum, indicates an active participation in the project of abolishing all projects. Bataille's master, like Hegel's, by negating his own life and the conditions of his existence, achieves what Hegel calls mastery and what Bataille would call sovereignty.

\section{Sovereign Uselessness}

Sovereignty disrupts in a profound ${ }^{15}$ way the world of utility. Its birthplace is neither the petty calculations of the everyday nor the protestant

\footnotetext{
8 Georges Bataille, "Hegel, Mankind and History," in Georges Bataille: Essential Writings, ed. and trans. by Michael Richardson (London: Sage Publications, 1998), 123.

9 Friedrich Wilhelm Nietzsche, Sämtliche Werke: Kritische Studienausgabe in 15 Einzelbänden, ed. by Giorgio Colli and Mazzino Montinari (München: Deutscher Taschenbuch Verlag, 1988), 12: 9[35]. Hereafter cited as KSA.

${ }^{10}$ Ibid.

${ }^{11} \mathrm{Ibid}$.

12 What Nietzsche calls culture- Kultur. See Friedrich Wilhelm Nietzsche, On the Genealogy of Morality, trans. by Maudemarie Clark and Alan J. Swensen (Indianapolis: Hackett Publishing Company, Inc., 1998), 1, II. Hereafter cited as GM.

${ }^{13}$ Kojeve, Introduction to the Reading of Hegel, 4.

${ }^{14}$ Bataille, "Hegel, Mankind and History," 123.

15 'Profound' because it is a movement of negativity, therefore of action.

(c) 2016 George Papandreopoulos http://www.kritike.org/journal/issue 18/papandreopoulos june2016.pdf ISSN 1908-7330

(c) BY-NC-ND
} 
ethic of accumulation, but rather the limitless energy of the universe. ${ }^{16}$ The source of energy is, for Bataille, the sun: "Solar energy is the source of life's exuberant development. The origin and essence of our wealth are given in the radiation of the sun, which dispenses energy - wealth - without any return. The sun gives without ever receiving." 17 Consequently, Bataille parts ways from classical political economy in that he considers sources as excessive and not as scarce. The fundamental economic problem then becomes, for him, the management of the excessive energy of the universe, not the accumulation of capital to counteract scarcity. Following Marcel Mauss' anthropological readings on the nature of gift in archaic societies, Bataille creates his own version of the Nietzschean Rangordung, in which the highest value is awarded to the imprudent consumer of the excessive universal wealth, whereas the lowest value is awarded to the prudent slaves who "reduce their consumption to the necessities."18 The imprudent consumer occupies the highest place in the ladder of this social system, which turns upside down the accumulative ethic of capitalism in the Christian West. The task is to upset the bourgeois values of safety and utility. At the end there is nothing left, Bataille tells us, because everything has been gloriously consumed in what resembles Mauss' potlatch, the celebrations of exuberant consumption in which social value depends on the amount of wealth which is wasted. ${ }^{19}$ Bataille believes that life can only properly begin when the realm of slave (utilitarian) values has been left behind: "life beyond utility is the domain of sovereignty." 20

Like Bataille, Nietzsche also considers life to be an event of excessive energy and this 'excessiveness' will be called will to power. In Twilight of the Idols (1889) we read: "life as a whole is not a state of crisis or hunger, but rather a richness, a luxuriance, even an absurd extravagance [absurde Verschwendung]."21 Following the findings of William Rolph and Wilhelm Roux, who believed that organisms strive for growth and expansion over selfpreservation, Nietzsche associates life with the will to power, which is understood variously as growth, expansion, appropriation, or

\footnotetext{
${ }^{16}$ Georges Bataille, The Accursed Share, Vol. II, trans. by Robert Hurley (New York: Zone Books, 1989), 187.

17 Ibid., Vol. I, 28.

${ }^{18}$ Ibid., Vol. II, 198.

${ }^{19}$ Marcel Mauss, The Gift, trans. by W.D. Halls (Oxon: Routledge, 1990), 47.

${ }^{20}$ Bataille, The Accursed Share, Vol. II, 198.

${ }^{21}$ Friedrich Wilhelm Nietzsche, Twilight of the Idols, trans. by Duncan Large (Oxford: Oxford University Press, 1998), Recon. 14. Hereafter cited as TI. In similar fashion, he notes: "in nature, it is not distress which rules, but rather abundance [Ueberfluss], squandering - even to the point of absurdity [sogar bis in's Unsinnige]." See Friedrich Wilhelm Nietzsche, The Gay Science, trans. by Josefine Nauckhoff (Cambridge: Cambridge University Press, 2001), 349. Hereafter cited as GS.
}

(C) 2016 George Papandreopoulos http://www.kritike.org/journal/issue 18/papandreopoulos june2016.pdf ISSN 1908-7330 
incorporation. ${ }^{22}$ What is of interest to us is Nietzsche's determination to separate the will to power from the will to preservation. He does so because these opposing wills ${ }^{23}$ produce correspondingly differing anthropological types. The will to preservation he considers to be a sign of weak, to the point of unnatural, natures. "To wish to preserve oneself is a sign of distress, of a limitation of the truly basic life-instinct, which aims at the expansion of power and in so doing often enough risks and sacrifices self-preservation." ${ }^{24}$ Weak natures, like the bourgeoisie, are solely interested in preserving their type, in preserving the sickness that generates them; they are foreign to life as an event of growth or creativity. Nietzsche is adamant: "The herd strives to maintain a type ... The tendency of the herd is toward standstill and preservation. There is nothing creative in it." 25 On the opposite side stand the strong natures. Their strength is drawn from their ability to control the great number of contrary drives that constitutes them. ${ }^{26}$ Yet this strength has no guarantees of endurance. It is because the strong nature encompasses great battles and is the expression of great but competing powers that it is also always on the verge of collapse. Unlike the weak nature, whose onesidedness protects it from breaking down, the strong type's multifariousness leaves it exposed. "The higher type represents an incomparably greater complexity - a greater sum of co-ordinated elements: so its disintegration is also incomparably more likely. The 'genius' is the sublimest machine there is-consequently the most fragile." 27

\section{On Sovereign Time}

What is the time of unproductive activity? What is the time of the sovereign, of the one who has liberated himself from the demands of utility and has thoroughly embraced the value of the present? Bataille's response is that it has to be a time which aims at nothing, a time which is defined by no future teloi but only by the sovereignty of the moment, which becomes infinitely valuable. "We don't see the sovereign moment arrive, when

\footnotetext{
${ }^{22}$ Friedrich Wilhelm Nietzsche, Beyond Good and Evil, trans. by Judith Norman (Cambridge: Cambridge University Press, 2002), 259. Hereafter cited as BGE.

${ }^{23}$ Which themselves are nothing but unitary, since every will is a union of antithetical forces. See BGE: 19.

${ }^{24} G S: 349$.

${ }^{25}$ KSA: 11: 27[17]. My translation.

${ }^{26}$ See Friedrich Wilhelm Nietzsche, The Will to Power, trans. by Walter Kaufmann and R.J. Hollingdale (New York: Vintage Books, 1968), 966. Hereafter cited as WP. See also KSA: 11: 27[59]. This strength has nothing to do with the strength of the pre-internalised masters of $G M^{\prime} s$ First Essay. There, and Nietzsche is clear on this, the masters live the one-sided instinctual life of animals. This has nothing to do with the human 'proper,' which comes into existence with the first struggle among antithetical forces. On the masters' externalising power see GM: 1, 10-11. ${ }^{27}$ WP: 363, KSA: 13: 15[118].

(c) 2016 George Papandreopoulos http://www.kritike.org/journal/issue 18/papandreopoulos june2016.pdf ISSN 1908-7330

(c) BY-NC-ND
} 
nothing counts but the moment itself. What is sovereign in fact is to enjoy the present time without having anything else in view but this present time." ${ }^{28} \mathrm{~A}$ future-orientated time is for Bataille a servile time, a time that is in the service of production, and in extension of capitalism itself. Servile time demands (but also produces) a certain anthropological type, the same type whose conditions of existence Nietzsche had scrutinised in On the Genealogy of Morality (1887). That human type, who will control the future for the sake of production, will have to be able to anticipate that future. Anticipation is a key notion since it demands a high degree of calculability, which becomes possible through the reduction of the once-unknown future to something predictable which can be calculated with precision. Like in factory production, products and productive activity are measured, calculated, carefully planned, and executed. The future is thoroughly known. There are no surprises lying ahead. Nietzsche notes that before the rendering of the future as thoroughly known, man has to train himself into becoming "reliable, regular, necessary." 29 Only this anthropological type will be able to align himself into a future in the service of production. Production requires regularity, which also means that irregularity (and the corresponding anthropological type) must be the synonym of unproduction.

Bataille notes: "In efficacious activity man becomes the equivalent of a tool, which produces; he is like the thing the tool is, being itself a product. The implication of these facts is quite clear: the tool's meaning is given by the future, in what the tool will produce, in the future utilisation of the product; like the tool, he who serves - who works - has the value of that which will be later not of that which is." 30 The prioritisation of a future thoroughly associated with productive activity reduces man to the status of the tool. Man's value is extracted from the transcendent source of an imagined future. Because of that, man lives in a constant state of anguish which comes to be completed by death. Bataille maintains that death only exists insofar as man lives in anticipation of a future 'attainment' of oneself. It is because we have placed the value of our individual existence on an imagined projection, which we call 'future,' that we die. If we were to live thoroughly in the present, deriving our value solely from what is, we would be able to live without death, escaping the anguish of death. A sovereign existence "escapes death, in that he lives in the moment." 31 This moment is the moment of the liberation of time from the demands of the future, not only from a productive future but from all future. Bataille stresses that it is the anticipatory structure of human existence that confines man into the logic of productive time and thus also of

\footnotetext{
${ }^{28}$ Bataille, The Accursed Share, Vol. III, 199.

${ }^{29}$ GM: II, 2.

${ }^{30}$ Bataille, The Accursed Share, Vol. III, 218.

${ }^{31}$ Ibid., 219.
}

(C) 2016 George Papandreopoulos http://www.kritike.org/journal/issue 18/papandreopoulos june2016.pdf ISSN 1908-7330 
death as that which lies at the end of the process of production. "The sovereign man lives and dies like an animal," 32 he lives only in the sovereignty of the moment which has liberated itself from all teloi.

\section{The Complications of Will}

The ambiguities of Bataille's notion of sovereignty, a type of power which is powerful as long as it is willing to let itself go, help us to understand better the usually misunderstood notion of will to power. We have seen, above, Nietzsche's aversion to the bourgeois idolisation of preservation, which he considers to be not a natural characteristic of human and non-human animals but rather the pernicious effect of culture. In reality, as he notes, "physiologists should think twice before positioning the drive for selfpreservation as the cardinal drive of an organic being. Above all, a living thing wants to discharge its strength-life itself is will to power ..."33 This power comes to refer to a notorious series of "appropriation, injuring, overpowering, oppressing, imposing, exploiting ..." ${ }^{34}$ Even if the kind of power for which Nietzsche speaks here is what interpreters call "metaphysical," 35 one cannot help but observe that even within the metaphysical model, someone, or rather something (a force), is to oppress and something else is to be oppressed. However necessary Nietzsche thinks that that is for life, it is certainly not particularly pleasant, not only for the one which gets oppressed but also for the one which oppresses. ${ }^{36}$ The stultifying effect of power does not only affect political actors ${ }^{37}$ but also forces, which, by overpowering other forces and exterminating opposition, 'unwittingly' come to remove the reason of their existence as forces within the greater game of power in which they are implicated.38 Despite power's notoriety, and Nietzsche's own inflamed rhetoric, in what follows I would like to argue that Nietzsche had experimented throughout his career with the possibility not only of setting limits to power but also with the prospect of abolishing it altogether, not because of caprice or weakness, but because it is in the very

\footnotetext{
32 Ibid.

${ }^{33}$ BGE: 13.

${ }^{34}$ Ibid., 259.

${ }^{35}$ Metaphysical power denotes the 'being' of the world, what the world ultimately is.

${ }^{36}$ In TI: "What the Germans Lack," 1 . Nietzsche had observed that "power stultifies [die Macht verdummt]."

37 The TI quote refers to political power, particularly the tendency of Germans to dominate, which, as Nietzsche believes, is what ultimately makes them stupid (verdummt).

${ }^{38}$ In the most characteristic of the passages supporting the metaphysical interpretation of the will to power, Nietzsche describes power as "a play of forces [Spiel von Kräften] and waves of forces, at the same time one and many, increasing here and at the same time decreasing there; a sea of forces flowing and rushing together ..." WP: 1067, KSA: 11:38[12].

(C) 2016 George Papandreopoulos http://www.kritike.org/journal/issue 18/papandreopoulos june2016.pdf

ISSN 1908-7330
}

(c) BY-NC-ND 
nature of power, as I will shortly argue, to flirt with what threatens to annihilate it. ${ }^{39}$ Nietzsche's endeavour to restrict power takes place for reasons internal to the dynamic of the will to power and for reasons external to it. The internal reasons are related to the constitution of will and the constitution of power. The external reasons are related to the two major steps in which Nietzsche deals with power. The first step describes Nietzsche's early struggle with the notion of agon, the typical case of restricting power, and the second step describes Nietzsche's meditations on the problem of the eternal return, which I read as Nietzsche's attempt to deconstruct the linearity of Christianproductive time and thus also to deconstruct the power-structures that have produced the domesticated animal which we have been trained to call 'man.' Ultimately, the thought of the return is a thought concerning the possibility of power to exist through that which perennially opposes it and is Nietzsche's final ${ }^{40}$ step in dealing with power.

Let me now briefly examine the internal reasons for the inevitable powerlessness of power. Rather than expressing powerfulness, simple and clear, the notion of the will to power is ambiguous. Its ambiguity rests primarily in the obscurities of its constitution as will, and secondly in Nietzsche's own idiosyncratic definition of power. To begin with, and strictly speaking, the very utterance of the word 'will' is only a sign of the human need to falsify the world by simplifying it, which means by reducing it to the categories of the one and the many, which, however helpful they are for orienting humans in the world, remain nevertheless the expression of prejudices exacerbated by the help of popularising philosophers like Schopenhauer. ${ }^{41}$ There is nothing simple or unified in the "will:' "will" is "complicated." 42 Nietzsche believed that the notion of unity [Einheit] is only something fictional that humans derive from their own psychic experience. In reality, unities are multiplicities structured around hierarchical principles and finding themselves in dynamic antagonism. Interestingly, in his own copy of Lange's Geschichte des Materialismus (1866), Nietzsche had found and marked the following passage from Goethe: "Every living thing, is not a single thing, but a plurality; even insofar as it appears to us as an individual,

${ }^{39}$ Any other conception of power, e.g. as an annihilating force, belongs to either a Naziinfluenced reading (present on Heidegger's 'Nietzsche' but gradually fading away on his later "What is called Thinking?") or to popular selective readings of Nietzsche's vast oeuvre.

40 The eternal return is the final step of Nietzsche's meditations on power both chronologically but also, most importantly, in terms of quality and finesse.

${ }^{41}$ On the subject of falsification see Peter Bornedal, The Surface and the Abyss: Nietzsche as Philosopher of Mind and Knowledge (Berlin: Walter de Gruyter, 2010), 195-196.

${ }^{42}$ BGE: 19. In reality 'will' does not even exist (as a unity). In WP: 488, KSA: 12: 9[98] Nietzsche declares that: "Aber es giebt keinen Willen." Also: "There is no will: there are treaty drafts of will that are constantly increasing or losing their power." WP: 715, KSA: 13: 11[73].

(C) 2016 George Papandreopoulos http://www.kritike.org/journal/issue 18/papandreopoulos june2016.pdf ISSN 1908-7330 
it still remains a collection of living independent beings." 43 That we need unities is not an argument for the existence of such unities, it is only a testament to the various failures of our psychic apparatus. In a revealing Nachlass note, Nietzsche states: "We need 'unities' in order to be able to reckon: that does not mean we must suppose that such unities exist. We have borrowed the concept of unity from our 'ego' concept-our oldest article of faith. If we did not hold ourselves to be unities, we would never have formed the concept 'thing.' Now, somewhat late, we are firmly convinced that our conception of the ego does not guarantee any actual unity." 44 Willing is "something unified only in a word" 45 while in reality it describes a battlefield of forces which command and forces which obey, in eternity. This willing, at once one and many, is the outcome of the "synthetic concept of the ' $\mathrm{I}$, '" 46 what, only out of habit, we call 'I,' 'subject,' 'ego,' or soul, all grammatical unities utilised though to express eine tausendfache Complexität. ${ }^{47}$ Nietzsche recognises the stalemate to which language drives him. For lack of a better word, he speaks of a something [Etwas] which expresses "the center of [a] system constantly shifting." 48 The will of the will to power, then, rather than articulating the determination of the one, expresses a unity only as organisation ${ }^{49}$ of the opposing forces which seek to express themselves within the system of powers which we call body [Leib] and resembles a society in that it is constructed by many "souls," 50 which is to say by many unified multiplicities manifesting their oneness only in the popularised superficiality of the grammatical level.

We have seen that the 'will' that wills power is anything but determinate. And yet will is still directed toward something (Macht). The fact of the directionality of the will should not be confused with some kind of authoritarian determinedness in the heart of the will. The will is directed toward something, because everything is directed toward something, in the sense of moving, ${ }^{51}$ without implying that movement ever reaches a final

43 Albert Frederick Lange, The History of Materialism, Vol. III, trans. by E.C.T. Paul Kegan (Trench: Trübner \& Co Ltd., 1925), 38. The information about Nietzsche's marking of the Goethe passage is provided by Gregory Moore, Nietzsche, Biology and Metaphor (Cambridge: Cambridge University Press, 2002), 35.

${ }^{44}$ WP: 635, KSA: 13:14[79].

${ }^{45}$ BGE: 19.

${ }^{46}$ Ibid.

${ }^{47} \mathrm{KSA}: 13,14[145]$.

48 WP: 488, KSA: 12:9[98].

${ }^{49}$ WP: 561, KSA: 12:2[87].

${ }^{50} B G E: 19$. Nietzsche refers here to the notion of the cell-state.

51 "We cannot imagine becoming other than as the transition from one persisting 'dead' state to another persisting 'dead' state." KSA: 9, 11[150], trans. by Robin Small in Robin Small, Time and Becoming in Nietzsche's Thought (London: Continuum, 2010), 4.

(C) 2016 George Papandreopoulos http://www.kritike.org/journal/issue 18/papandreopoulos june2016.pdf

ISSN 1908-7330

(c) $\mathrm{BY}-\mathrm{NC}-\mathrm{ND}$ 
state. ${ }^{52}$ Yet the will is not moving toward any direction but specifically toward Macht. Why is that? I would like to argue that the will moves toward what mostly resembles it and that is Nietzsche's own version of power. Will and power are related by their internal structure, which is none other than that of ambiguity. On the one hand, will is certainly the will to overpower something, even when simultaneously will also 'knows' that it cannot overpower the opposing force since that would bring the 'game of forces' to an unforeseen end. The flux of forces is eternal and will remain so. On the other hand, will is internally related to Macht, because there it sees the mirror image of itself. It is attracted by what is ambiguous, as will itself is.

\section{Power Bound}

The question of power ${ }^{53}$ is certainly one of the most important subjects in Nietzsche's bibliography. Here I am not interested in examining power as a psychological motivator or as a political principle, but solely in shedding light to some aspects of the internal dynamic of power (or the ontology of power), specifically those which will support my claim for the ultimate powerfulness of power. There is no question that power refers to a force of appropriation and overcoming, otherwise Nietzsche would not use the very word "power." However, Nietzsche makes a distinction which goes usually unnoticed, that between Kraft and Macht. Kraft is essentially a leftover of the "mechanistic view of the world," 54 itself an anthropomorphisation of nature whereby we assign relations of causes and effects to the world in order to comprehend it. ${ }^{55} \mathrm{Kraft}$ is supposed to express a "primitive energy" ${ }^{56}$ which originally creates and sustains nature through relations of regularity and necessity. However, these relations simply do not exist. The only things that exist are relations of power that behave irregularly, unpredictably, and in an undisciplined manner. This 'power-will' is not, rather it 'radiates' [diese Strahlung von Machtwillen] through the whole of being [das ganze Sein], and as

52 "If the motion of the world aimed at a final state, that state would have been reached. The sole fundamental fact, however, is that it does not aim at a final state ..." WP: 708, KSA: 13: $11[72]$.

${ }^{53}$ We owe much of our understanding of power to the tireless efforts of Jacob Golomb. See: Jacob Golomb, Nietzsche's Enticing Psychology of Power (Ames: Iowa State University Press, 1989), see also Jacob Golomb, "How to De-Nazify Nietzsche's Philosophical Anthropology," in Nietzsche, Godfather of Fascism? ed. by Jacob Golomb and Robert S. Wistrich (Princeton and Oxford: Princeton University Press, 2002), 19-46, and Jacob Golomb, “Will to Power: Does it Lead to the 'Coldest of All Cold Monsters'?" in The Oxford Handbook of Nietzsche, ed. Ken Gemes and John Richardson (Oxford: Oxford University Press, 2013), 525-550.

${ }^{54}$ WP: 618, KSA: 11, 36[34]

55 WP: 624, KSA: 12:7[56].

${ }^{56}$ Golomb, “Will to Power: Does it Lead to the 'Coldest of All Cold Monsters'?", 527.

(C) 2016 George Papandreopoulos http://www.kritike.org/journal/issue 18/papandreopoulos june2016.pdf

ISSN 1908-7330

(cc) BY-NC-ND 
radiation eventually escapes the 'mechanistic order' which cannot capture it. $^{57}$

Because the world does not behave in a mechanical and regular way, Kraft is an inappropriate concept to describe the relations permeating nature. "The victorious concept 'force' [Kraft], by means of which our physicists have created God and the world, still needs to be completed: an inner will must be ascribed to it, which I designate as 'will to power,' i.e. as an insatiable desire to manifest power [Macht] ..."58 This 'will to power,' which expresses "the degree of resistance and the degree of superior power," 59 is what is left over after we have extracted from the world our successive layers of anthropomorphisms.

If we eliminate these additions [number, thing, activity, motion], no things remain but only dynamic quanta, in a relation of tension to all other dynamic quanta: their essence lies in their relation to all other quanta, in their 'effect' upon the same. The will to power not a being, not a becoming but a pathos - the most elemental fact from which a becoming and effecting emerge. ${ }^{60}$

Nietzsche believes, then, that being or becoming can be grounded in something elemental, which, however, is not a being. The etymological richness of the word pathos does not help to clarify its relation to power. Is power a quality of things, or perhaps an unfortunate accident? Is power a sensation or a calamity and a defeat? ${ }^{61}$ Certainly Nietzsche seems to prioritise the elemental character of pathos, yet as a distinguished classical philologist and passionate anti-Christian could not remain oblivious to the strong connotations of 'internal suffering' that befalls the mind, nor to the later Christianised long history of explicating pathoi as the evil and lustful wishes of the soul that have to be eradicated. ${ }^{62}$

If power suffers, then, it is because power is, and never was, too sure of itself. My argument concerning power is that it is unstable from the very moment of its constitution as power, because the forces which constitute it are in a constant antagonism with each other, which does not allow for one force to overpower the other. The agon in power is eternal. But before explaining

${ }^{57}$ KSA: 13: 14[79].

58 WP: 619, KSA: 11:36[31].

${ }^{59}$ WP: 634, KSA: 13:14[79].

${ }^{60}$ WP: 635, KSA: 13:14[79].

${ }^{61}$ Some of the meaning of pathos in George Henry Liddell and Robert Scott, A Greek-

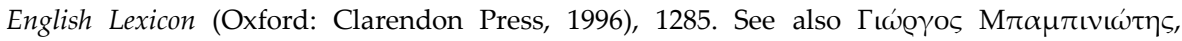

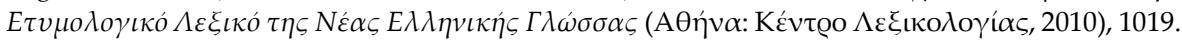

${ }^{62}$ See Romans 1:26, Colossians 3:5.1, Thessalonians 4:5.

(c) 2016 George Papandreopoulos

http://www.kritike.org/journal/issue 18/papandreopoulos june2016.pdf

ISSN 1908-7330

(c) $)$ BY-NC-ND 
the hydraulics of power, let us take a step back toward describing the sublimating character of power in relation to force. In one of the most interesting passages on the problem of power, Nietzsche notes:

We are still on our knees before strength [Kraft] after the ancient custom of slaves - and yet when the degree of worthiness to be revered is fixed, only the degree of rationality in strength is decisive: we must access to what extent precisely strength has been overcome by something higher, in the service of which it now stands as means and instrument!

He concludes the aphorism by noting that the characteristic of the "great human being" is his "victory over strength." 63 The aphorism makes clear that the distinctive mark of the human, over its pre-human, animalistic past, is its capacity to sublate the physicality of force by transfiguring it into something higher, namely power. Force is appropriate to slaves because it is something simple, it is only a matter of 'mechanics,' whereas power, like will, is complicated.

The complicated character of power arises from its agonistic constitution. In an illuminating Nachlass note, Nietzsche gives his most precise definition of power: "The will to power can manifest itself only against resistances [Widerständen]; therefore, it seeks that which resists it." 64 We have to be clear on how we interpret this crucial passage. Nietzsche says that the precondition for the very existence of power is resistance. Resistance is what generates power. Power only exists because, and for as long as, there is resistance. This makes clear that power does not and cannot stand alone but needs another in order to constitute it as power. Not just any other, but another which actively opposes it. Resistance and power are the two poles that constitute the thing Nietzsche calls Macht. In a similar fashion, in Ecce Homo (1908), where Nietzsche explicates the rules under which one is to launch and conduct war, he notes: "The strength of an attacker can in a way be gauged by the opposition he requires; all growth makes itself manifest by searching out a more powerful opponent." 65 Equally, in a Nachlass note from Spring 1888, he writes: "A quantum of power is designated by the effect it produces and that which it resists. The adiaphorous state is missing ..."66

63 Friedrich Wilhelm Nietzsche, Daybreak, trans. R.J. Hollingdale (Cambridge: Cambridge University Press, 1997), 548. Hereafter cited as D.

${ }^{64}$ WP: 656, KSA: 12:9[151]

${ }^{65}$ Friedrich Wilhelm Nietzsche, "Why Am I So Wise?" in Ecce Homo, trans. by Duncan Large (Oxford: Oxford University Press, 2007), 7. Hereafter cited as EH.

${ }^{66}$ WP: 634, KSA: 13: 14[79].

(C) 2016 George Papandreopoulos http://www.kritike.org/journal/issue 18/papandreopoulos june2016.pdf ISSN 1908-7330 
Power is dynamic since it always strives for more, for a maximum feeling of power, ${ }^{67}$ and is structurally relational. Ciano Aydin stresses the following:

Nietzsche's principle of the will to power implies that relation is not an additional element of things but, rather, something that constitutes in a fundamental way what a thing is. In other words, there are no first things, which then have relations with each other; rather, things are what they are by virtue of their relations. ${ }^{68}$

The structural relationality of what Aydin calls the 'thing', or the nature of reality, produces a dynamic relation of power(s) and resistance(s) which motivates a process where powers, or the drives which constitute power (whose intrinsic characteristic is growth), always "lust for more" 69 through their unbreakable relation. John Richardson has developed the interesting line of reasoning whereby drives, through their striving toward the maximisation of their potency, always aim to achieve some state of power. Yet this state is never actually reached since this would signpost the coming of what Nietzsche has called a state of adiaphoria. If the overcoming of resistances is the principal characteristic of the will to power, then the overcoming of drives brings about a non-state of perennial overcoming, and that will mean that it brings about the overcoming of power itself. ${ }^{70}$ As Richardson notes, "To be a will to power, it must already want something other than power."71 Due to its internal constitution, as an agonistic interrelation of forces which always strive to rule, will to power brings about its self-overcoming and becomes indeed something other than power, which is to say it becomes what it already was: overcoming. Nietzsche, then, through his building of a paradoxical core-inhabiting power, subverts the traditional understanding of power as achievement, possession, control, or capacity, and turns it on its head. The controlling or possessive power is the power which will eventually overcome control or possession and will become potentiality instead of actuality. Thus, the will to power signifies not the will to this or that end, but rather the will to an end which overcomes itself, to a passage through which the will to power will continue to grow as potentiality. To put it briefly, Nietzschean power is not there to win anything, but to lose itself, as actuality; and through that act of profound losing, to gain itself as

\footnotetext{
${ }^{67}$ KSA: 13: 14[82].

${ }^{68}$ Ciano Aydin, "Nietzsche on Reality as Will to Power: Toward an 'OrganizationStruggle' Model," in Journal of Nietzsche Studies, 33 (2007), 26.

${ }^{69}$ WP: 481, KSA: 12: 7[60].

${ }^{70}$ John Richardson, Nietzsche's System (Oxford: Oxford University Press, 1996), 22-23.

${ }^{71}$ Ibid., 23.
}

(c) 2016 George Papandreopoulos http://www.kritike.org/journal/issue 18/papandreopoulos june2016.pdf ISSN 1908-7330 
potentiality. This is why Nietzsche prescribes to his readers to exercise the principle of 'great suffering,' which is great insofar as it does not consume itself into masochistic self-flagellation for the benefit of a narcissistic occupation with the self. ${ }^{72}$ Great suffering, as the practice of great losing, becomes the precondition for the enhancement of the whole human species. Paradoxically, Nietzsche seems to suggest, the greatest exercise of power is for the power to be incorporated, ${ }^{73}$ because by this act of incorporation it comes to be transformed into something greater and stronger than it was.

\section{Eternal Return or Sovereignty in Ruins}

Notoriously, there are as many interpretations of Nietzsche's infamous thought concerning eternal return as there are readers of Nietzsche's oeuvre, perhaps even more. Here I am interested in clarifying solely the following aspect of the thought of the return. I wish to argue that this thought is a thought that continuous and completes Nietzsche's meditations on power. I have shown before that Nietzsche promoted a power which becomes sovereign only after its acceptance of the inevitability of its powerlessness. In a similar fashion, I wish to argue that Nietzsche believes that in order to liberate time from the bonds of linearity ${ }^{74}$ time has to embrace loss and unproduction. That can be done only by liberating time from the bonds of the past, from the demands and the awards of the future, and from a present that is only insofar as it serves something other than the sovereignty of its moment, of the moment. Circular non-nihilistic time is a time directed toward life: not life as a project to be completed in some ideal future time and under certain prescriptions and demands, but rather life as the glorious manifestation of the primordiality of the forces which constitute its eternal flux. Eternal return is an experiment in a time which loses itself, loses the projects of everydayness and the various authoritarianisms of social structures aiming solely in a life concentrating in accumulation and production.

Thus Spoke Zarathustra (1883) opens with Zarathustra's remarkable statement concerning the necessity of his going under [Ich muss ...

72 “... for your true nature lies, not concealed deep within you, but immeasurably high above you, or at least above that which you usually take yourself to be." Friedrich Wilhelm Nietzsche, "Schopenhauer as Educator," in Untimely Meditations, trans. by R.J. Hollingdale (Cambridge: Cambridge University Press, 1997), 1. Hereafter cited as UM.

${ }^{73}$ BGE: 259

${ }^{74}$ Linearity is guilty, since it has produced the docile human type depicted in GM, a human type which is enslaved into a logic of production and future awards in the name of which the present loses all its value. Ultimately, the thought of the return is the attempt to eternalise the moment, to value the moment, against the eternal transitoriness of valueless moments.

(C) 2016 George Papandreopoulos http://www.kritike.org/journal/issue 18/papandreopoulos june2016.pdf ISSN 1908-7330 
untergehen]. ${ }^{75}$ Untergehen is a verb describing not only a descent (toward something), but also destruction. In that sense, Ich muss ... untergehen means: "I must destroy [myself]" or "I must perish." Commentators ${ }^{76}$ are right in underlining the importance of Zarathustra's descent as the antipode to Platonic/ Christian culture which ascends toward [divine] light (or turns toward light, as in Plato's parable of the cave) in its attempt to approach the transcendent truth. Zarathustra the teacher follows a different path. Instead of ascending, and leaving behind what he finds unworthy of the contemplation of the divine logos, he descends and takes with him (incorporates) everything that has been neglected by the Platonic/ Christian culture: the data of experience, the experience of the body, senses, etc. All of the above is certainly true. However, one must not lose sight of Zarathustra's literal use of untergehen. Zarathustra really has to perish, really has to destroy himself, really has to beat himself to the ground, so to speak, if he is to be worthy of his vocation as the teacher of the one who goes over, the Overhuman. ${ }^{77}$ This literal use of untergehen is reinforced further in the text, when Zarathustra makes an even more remarkable calling to one's selfdestruction: "I love those who do not know how to live except by going under [als Untergehende], for they are those who go over and across."78 Here Zarathustra makes a rather powerful claim: he tells us that, unfortunately, and despite the plethora of self-help literature, ultimately there does not exist a guidebook in life, something that can guide us around this mystery of our lives. But Zarathustra further suggests that he will give all his love only to those who will live by destroying themselves. To be able to live beyond life, beyond the burden of self-preservation, is to want to perish. Ultimately the sovereign, the Overhuman, is going to be the human willing to abandon himself so that he can find himself. ${ }^{79}$ This is what characterises the

\footnotetext{
${ }^{75}$ Friedrich Wilhelm Nietzsche, "Prologue" in Thus Spoke Zarathustra, trans. by Graham Parkes (Oxford: Oxford University Press, 2005), 1. Hereafter cited as TSZ.

${ }^{76}$ Laurence Lampert, Nietzsche's Teaching: An Interpretation of Thus Spoke Zarathustra (New Haven and London: Yale University Press, 1986), 16. See also Stanley Rosen, The Mask of Enlightenment: Nietzsche's Zarathustra (New Haven: Yale University Press, 2004), 28.

77 Burnham \& Jesinghausen successfully spot this literal and yet neglected use of untergehen. Douglas Burnham and Martin Jesinghausen, Nietzsche's Thus Spoke Zarathustra (Edinburgh: Edinburgh University Press, 2010), 16.

78 TSZ: Prologue, 4.

${ }^{79}$ Here the idea of self-sacrifice is prevalent. The Christian-sounding formulation of the sentence is indeed provocative and urges us to clarify the kind of sacrifice Nietzsche speaks about. Does Nietzsche rightly sound 'too Christian' with his idolisation of self-sacrifice, or does he speak for something other than what a Christian will understand? In her outstanding essay "Justice and Gift-Giving in Thus Spoke Zarathustra" Vanessa Lemm attempts to provide an answer to the above-mentioned problem. Lemm maintains that the practice of gift-giving in Zarathustra is to be differentiated from that of charity and alms, since while the former promotes the distance between the one and the other, acknowledging thus the "other's irreducible singularity," the latter promotes "a hierarchical relationship of domination which not only reinforces dependency
}

(C) 2016 George Papandreopoulos http://www.kritike.org/journal/issue 18/papandreopoulos june2016.pdf ISSN 1908-7330

(c) BY-NC-ND 
Overhuman. He is not the power that dominates, but rather the power that sacrifices [itself] so that he can further live as power.

In a Nachlass note from 1883, Nietzsche notes: “The absolute necessity of a total liberation from ends: otherwise we should not be permitted to try to sacrifice ourselves and let ourselves go. Only the innocence of becoming gives us the greatest courage and the greatest freedom!" 80 The note is interesting for many reasons and it can be argued that it paves the way to my reading of the thought of the return. The note's compelling claim is the link between the exigency of man's disengagement from any logic of teloi and the prospect of absolute freedom which this liberation promises. Improvement is a key notion in Christian religion, and ascetic practices necessarily accompany a life dedicated to self-cultivation with regard to transcendental aims. In his $G M$, Nietzsche has shown how the ascetic life that the priest imposes as a value upon the masses of the heteronomous slaves has hindered their realisation of the immensity of the forces which constitute them and has forever sealed them in a protective cocoon against the threat of nihilism, i.e. the threat of having to 'dare' to create their own meaning of their existence. But Nietzsche makes also another, perhaps more audacious, claim. He asserts that the freedom one gets from the innocence of becoming is not so much a freedom from $\mathrm{X}$ or $\mathrm{Y}$, but rather a freedom to something very specific, namely selfsacrifice. ${ }^{81}$ He insists that the alternative vision to the current Western model of living life according to a project is the utter disassociation of human existence from the bounds of existence itself. Nietzsche's abhorrence of a life of mere survival is well-known, but on this note he calls for something more. Man is not to be the animal fighting for his 'right' to existence (to be is a privilege anyway); as long as he does that he dedicates his life to something

and injustice but also stirs feelings of resentment and revenge." Lemm further argues that the crucial difference between Nietzschean and Christian sacrifice is the selflessness/ egoism dichotomy. Christian sacrifice is only superficially selfless. In reality, it is the result of an impoverished will. The 'love for one's neighbour' only shows an absence of a self and someone who cannot 'stand himself.' Love for the neighbour is a compensation for the absence of the love to one's self. It is an attempt to "compensate for one's own interior emptiness." On the contrary, the Nietzschean squanderer's self-sacrifice is an expression of an 'overflowing of the self;' the squanderer gives (he gives himself not objects) because he is too 'full of him,' he is too much and thus he has to give away. Lemm notes that "Nietzsche compares the overflowing of the self ... to the natural movement of a river overflowing its banks. Both movements are 'involuntary (unfreiwillig):' they illustrate the idea that gift-giving is not an act which can be traced back to an intentional subject, a conscious decision, or a willful act. Gift-giving occurs inevitably, fatefully, involuntary. The giver of gifts gives him- or herself over to the other not because they are free to give, but because he or she is not free not to give." See Vanessa Lemm, "Justice and Gift-Giving in Thus Spoke Zarathustra", in Nietzsche's Thus Spoke Zarathustra: Before Sunrise, ed. by James Luchte (London: Continuum, 2008), 165-181.

${ }^{80}$ WP: 787. KSA: 10:8[19].

81 TSZ: On Bestowing Virtue.

(C) 2016 George Papandreopoulos

http://www.kritike.org/journal/issue 18/papandreopoulos june2016.pdf

ISSN 1908-7330

(cc) BY-NC-ND 
petty, i.e. to himself. Man is the animal who is ready, at all times, to let himself go, to sacrifice himself.

We have seen above how Zarathustra's inaugural speech conveys the ambivalence of a movement that has to be a going under so that it can eventually be also a going over. Transitions and movements of this sort are prevalent throughout TSZ and they reach their peak at every mention of the thought of 'the return.' The chapter "The Convalescent" is one of those characteristic moments of Nietzschean dialectics where opposites meet only to be melted into a whole which is going to move the narrative forward. The chapter is concerned with the fate of the lowest, of that which does not deserve existence since all it can do is to accuse and debase it. Zarathustra is horrified at the idea that he may himself have to be what he loathes most: an accuser of humanity. Why does Zarathustra even dare to contemplate such a defeatist thought? How could he, the eulogist of all joy that comes from attending to the needs of the earth and of those who live according to nature's (chaotic) demands, turn against his own mission? Yet Zarathustra confesses to his animals, life's enigmatic teaching: "Ah, my animals, this alone have I learned so far, that for the human, its most evil is necessary for its best" and that the human "must become better and more evil." 82 The West has advanced so far by a process of exclusion, which was originally based on the Platonic teaching concerning the contemplation of the Forms. Nietzsche wishes to overturn the Platonic/ Christian model of exclusion by advancing an interpretation of the human which is based on incorporation. The new type of the human advanced by Nietzsche is not going to exclude the other but incorporate it; that is the meaning of Zarathustra's advice to become more evil. We have to welcome what until now has been deemed unworthy, evil, inferior; only by this process of incorporation eventually we are going to learn; the rest is cowardice, in the most Kantian sense. Naturally, the process is not going to be easy. In a note from 1887 Nietzsche observes: "The time has come when we have to pay for having been Christians for two thousand years." 83 The thought of incorporation is difficult to swallow even for Zarathustra. He literally chokes at the idea of a "great loathing for the human." And yet he has to accept the greatest of all thoughts, that the love of his fate and the eternal return of all things demands also the return of the most despicable, of the most nauseating form of human animal, the return of the lowest: the last human, the complacent bourgeois, the Christian, the socialist, the democrat, the cultural philistine. "Ah, disgust! disgust! disgust!" cries Zarathustra at the realisation of the necessity of the eternal return of the smallest human being. ${ }^{84}$

\footnotetext{
82 TSZ: The Convalescent.

${ }^{83}$ WP: 30. KSA: 13:11[148].

${ }^{84}$ TSZ: The Convalescent.
}

(c) 2016 George Papandreopoulos http://www.kritike.org/journal/issue 18/papandreopoulos june2016.pdf ISSN 1908-7330

(cc) BY-NC-ND 
To be sure, Zarathustra does not endorse the return of something changed, but the return of the same conditions that bring about life as a possibility of growth and incorporation. A few lines further, Zarathustra insists that he will eternally return to "this self-same life [zu diesem gleichen und selbigen Leben] ... not to a new life or a better life or a similar life." 85 Is this equivalent with the return of the identical?86 Nietzsche clearly believes that the life which returns is the same as the life already lived. Yet his rhetoric gets ahead of him, since it promotes something qualitatively different to what even Nietzsche believes that he endorses. The typical example is "The Drunken Song" from the fourth part of TSZ. There Zarathustra praises Joy, for it wants all eternity. A life of joy seeks to incorporate in it everything that up to now has been left outside the corpus of 'approved' life for the humans. Joy wants all that life has to offer, beyond judgments and exclusions. Indeed, "so rich is joy that she thirsts for woe, for Hell, for hate, for disgrace, for the cripple, for world ... You superior humans, it is for you that she yearns, this

85 Ibid.

86 The matter concerning the return of the same as identical is famously much discussed by Gilles Deleuze. Deleuze argued that the eternal return does not refer to a return of identical events, but rather on the event of the return itself. What returns in the return is not 'facts' but the very act of returning, which returns as eternally differing since being and becoming are intertwined: "That everything returns is the closest approximation of a world of becoming to a world of being ..." That Deleuze heavily relied on mistaken French translations for his undoubtedly original exposition of the return is now well-known. (For more on this issue see: Paolo D'Iorio, “Nietzsche et l'éternel retour. Genèse et interprétation”, in Nietzsche. Cahiers de l'Herne (Paris : L'Herne, 2000), 361-389. For an English: translation, see Paolo D'Iorio, "The Eternal Return: Genesis and Interpretation," trans. by Frank Chouraqui, in Nietzsche Circle: A Philosophical Community (April 2011), < http://www.nietzschecircle.com/Pdf Diorio Chouraqui-FINAL APRIL 2011.pdf $>, 4$ April 2016. However, this does not minimize his contribution to efforts to provide Nietzsche with a way out of the deadlock that his apparent insistence on the sameness of the same in which returns had trapped him. Deleuze was certainly right in insisting that a type of identical sameness would remove from Nietzsche his right to an educational philosophy of overcomings, which is something that we still ought to safeguard today. But Deleuze makes also another, rather problematic, move in two steps. First, he invents a dichotomy that is highly unlikely to ever have existed in Nietzsche's work, that between active and reactive forces, and in a second step he understands what he calls 'reactive forces' as essentially nihilistic. This requires him to deny the eternal return of 'the reactive' as inconsistent and contradictory to Nietzsche's affirmative philosophy. On the first step: "Neither the word nor the concept of 'reactive forces' ever appears in Nietzsche's philosophy." See D'Iorio, "Nietzsche et l'éternel retour. Genèse et interprétation." Cf. Marco Brusotti, "Die 'Selbstverkleinerung des Menschen' in der Moderne : Studie zu Nietzsches 'Zur Genealogie der Moral," in Nietzsche-Studien, 21 (1992), 83, 102-103; Gilles Deleuze, Nietzsche and Philosophy, 1962 ed., trans. by Hugh Tomlinson (London: Continuum, 1986), 46-47 passim. To be sure Nietzsche does speak for reactive affects or reactive men, as in GM: II, 11, but this has nothing to do with the concept of a reactive force. Rather than reactive [Kraft] Nietzsche utilizes the concept of resistance [Wiederstehen] in order to express the antithetical and yet interrelated life of the Macht, as in KSA: 13: 14[79] and 12: 9[151]. On the second step, see Deleuze, Nietzsche and Philosophy, 6465.

(C) 2016 George Papandreopoulos http://www.kritike.org/journal/issue 18/papandreopoulos june2016.pdf ISSN 1908-7330 
joy, intractable, blissful for your woe, you that have failed! For failures does all eternal joy yearn." 87 The passage raises many problems in relation to the thought of the return. What does it precisely mean that joy seeks the return of hate? It possibly means that joy, which wishes the return of all things, wishes also the incorporation of such a fundamental source of human knowledge as hate. According to Nietzsche's agonistic model of life (power), one (one person, one culture) is the locus of antithetical forces fighting for victory. The 'victory' of a force is the recognition of the power of the other force. Joy, then, would not be a joy at all if it didn't seek the other which completes it. It needs the other the same way the master in Hegel's Phenomenology needs the slave in order to recognise him. However, Nietzsche goes one step further. Joy also needs Hell [Hölle]! Is the mention of hell made in order to exaggerate the conditions of resistance that joy needs in order to express itself, or as a premonition of the Christian condemnation that awaits this overfull joy which seeks all eternity? What does it mean precisely to suggest that, through the thought of the return, humanity should wish also the return of hell? Does it mean that humanity should seek the return of the conditions that will bring her [humanity] down?

The next line further complicates the matter. Zarathustra, turning to the 'superior humans' (those who pave the way to the Overhuman but who are not yet Overhumans themselves), warns them that "it is for you that she yearns this joy ... for your woe, you that have failed! For failures does all eternal joy yearns." 88 What does it precisely mean to say that joy, which wants all eternity, seeks also the eternal return of failures? According to the agonistic model of power, a force, as long as it resists, can maintain itself both in life and in the agon. But what about failures? What about those who have simply failed to maintain themselves in the agon? Do they disappear? Here Nietzsche seems to suggest that even the most nauseating element in life will return also, because the joy of life, the willingness to incorporate the whole range of human experience, is so great that joy will not exclude anything. Nietzsche is on thin ice here. On the one hand he has repeatedly asserted the return to this 'self-same' life which is not going to be either 'new' or 'similar,' and on the other hand he declares the return of failures as if what has failed is not going to change the kind of life that one lives! To seek the return of all woe and all hell is not simply to seek the return of conditions of resistance as the agonistic model of power would demand; it is to actively seek that which can potentially fundamentally upset the very conditions of life as an agonistic relation of powers. It is not the case that the return wishes the return of an opposite. The return here seeks that which will perhaps challenge the very

${ }^{87}$ TSZ: The Drunken Song.

${ }^{88} \mathrm{Ibid}$.

(C) 2016 George Papandreopoulos

http://www.kritike.org/journal/issue 18/papandreopoulos june2016.pdf

ISSN 1908-7330

(c) BY-NC-ND 
conditions of the return itself. Otherwise a 'hell' is not hell, but something simply unpleasant.

As we have seen above ${ }^{89}$ Nietzsche believes that the will to preserve something signifies a weak nature, it is a sign of a declining life that resists the possibility of coming in contact with what can fundamentally challenge it. Nietzsche seems to suggest that a life that is too full of itself should not be afraid to prepare or even to welcome the conditions of its self-annihilation. The chapter "The Drunken Song" is Heraclitean in the most precise fashion, because it upsets every rule of logic; ${ }^{90}$ and yet it wants its central suggestion to be taken seriously: that joy, a life beyond the exclusions of the Western/ Christian paradigm, is not afraid to seek its own failure as well.

But the above cannot be a declaration of pessimism and a testimony of defeat. If it were that, then Silenus would have had to be right after all, and man's short sojourn upon the earth would be in vain. On another occasion, Nietzsche has warned all those who tend to spend themselves extravagantly (the 'higher types') that they should learn to conserve themselves, since this is the "greatest test of independence." ${ }^{91}$ To say that one has to be ready to wish failure is not the same as saying that one has to wish the eternal return of the conditions of failure. The former is getting ready to accept defeat while the latter wishes to incorporate the whole of life back to the cultural paradigm of the present. But Nietzsche is also telling us something else: that the wish of the return of the conditions of failure brings back the issue of the agonistic relation not only to one's own self but also to one's contemporaries. Ultimately one has to conserve himself against the fashions and the clamouring crowds of his times so that he can be ready to throw himself toward the right sort of agon. To be sure, there are competitions of all kinds, and then there are agons. Competitions are what the Roman crowds in the Colosseum (and their contemporary equivalents in public arenas) craved: in some cases, an exhibition of sheer power, in other cases, exhibitions of (socalled) beauty, possessiveness of things, etc. The end of competition is the annihilation of the other. In agonistic contests, on the other hand, the aim is the consolidation of the power of the one through the consolidation of the power of the other. There is a dialectic of forces at work here aiming again at an eternal overcoming, not at a final stage of closure. "And all the people laughed at Zarathustra." 92 Zarathustra comes to learn to conserve himself and

${ }^{89}$ See footnotes 23,24

${ }^{90}$ See this typical Heraclitean formulation: "Pain is also joy, curse is also a blessing, night is also a sun -be gone! or you will learn: a wise man is also a fool." TSZ: The Drunken Song, 10. Famously Aristotle himself had accused Heraclitus for violating the law of contradiction. Aristotle, Metaphysics, The Complete Works of Aristotle, ed. by Jonathan Barnes, Vol. II., trans. by W.D. Ross (Princeton: Princeton University Press, 1984), Г 1005, b 17-20.

${ }^{91}$ BGE: 41.

92 TSZ: Zarathustra's Prologue, 3.

(C) 2016 George Papandreopoulos http://www.kritike.org/journal/issue 18/papandreopoulos june2016.pdf ISSN 1908-7330 
not be wasted in pointless competitions. The crowds will never be ready to hear his message. He has thus to conserve himself for those who are ready (if any is), he has to prepare himself for the right sort of agons, for worthy opponents, ${ }^{93}$ whose opposition to him will ultimately honour him.

\section{Conclusion}

Zarathustra comes to the people with the sole purpose of presenting them with the gift of the possible arrival of that which will overcome the human without though leaving behind the human. Among the characteristics of this human of the future is its fundamental disregard for the preservation of its type. In order to go over the human of the future has first to go under, and this is where his overcoming lies. "I love him whose soul squanders itself, who wants no thanks and does not give back again: for he always bestows and would not preserve himself." 94 The Overhuman is a sovereign, but a sovereign without dominion. He has urged his disciples to abandon him ${ }^{95}$ and he keeps nothing to himself: "I, a squanderer with a thousand hands ... ${ }^{96}$ He knows that his sovereignty is his failure to persevere. He is not of the kind which endures. It is because higher types are concentrations of extreme contradictory forces that are pulling the centre apart that they are not meant to last. ${ }^{97}$

In this paper I have argued that Nietzsche, and his disciple Bataille, embrace an understanding of power that temporarily establishes itself through its willingness to 'let itself go.' Bataille develops his notion of sovereignty based on the Hegelian suggestion of a life that counts only to the extent that is willing to dissociate itself from the bounds of biological preservation. Bataille further suggests that it is because the cosmos is fully charged with excessive energy and lacks nothing that humans and their societies can exist in a state of permanent consumption, something that naturally upsets the laws of political economy and the current global spread of capitalist/ accumulative logic. I have argued that this move by Bataille was anticipated by Nietzsche. Rather than a type of power which imposes and dominates, Nietzschean power serves only the sovereignty of a moment which escapes the utilitarian calculations of the present. Inevitably, this power belongs wholly to the future; it belongs to "the Zarathustra-realm of a

\footnotetext{
${ }^{93}$ EH: Why I Am So Wise, 7.

${ }^{94}$ TSZ: Zarathustra's Prologue, 4.

95 TSZ: On the Bestowing Virtue, 3.

${ }^{96}$ TSZ: The Honey Offering.

${ }^{97}$ WP: 684, KSA: 13:14[133], see also TSZ: On the Superior Human, 15.
}

(C) 2016 George Papandreopoulos http://www.kritike.org/journal/issue 18/papandreopoulos june2016.pdf ISSN 1908-7330 
thousand years." ${ }^{\prime 98}$ In contrast, the present belongs to the rabble, ${ }^{99}$ which understands sovereignty and power solely in the context of wins and losses, of 'stuff' which one accumulates as one marches forward. Bataille, with his development of the idea of excessive energy, and Nietzsche, with his idea of the eternal return, have both resisted the teleological, and for both of them also moralistic, structure of history in favour of a perennially self-consuming and self-generating model that originates itself in the primordial battle of forces constituting the agon. Through my analysis of Bataille's and Nietzsche's views I have shown that the type of power they are contemplating opposes the type which was cultivated by the Western historical paradigm. Bataille's sovereignty and Nietzschean power demand the cultivation of conditions of resistance ${ }^{100}$ and thus render themselves ambiguous, complicated, and multifarious.

English and Creative Writing Department, Staffordshire University, United Kingdom

\section{References}

Antunes, Lobo Antonio, The Land at the End of the World, trans. by Margaret Jull Costa (New York \& London: W. W. Norton \& Company, 2011).

Aristotle, Metaphysics, The Complete Works of Aristotle, ed. by Jonathan Barnes, Vol. II., trans. by W.D. Ross (Princeton: Princeton University Press, 1984).

Aydin, Ciano, "Nietzsche on Reality as Will to Power: Toward an 'Organization-Struggle' Model,' in Journal of Nietzsche Studies, 33 (2007).

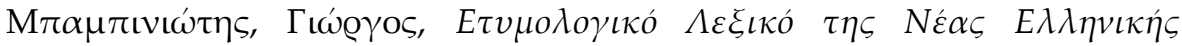

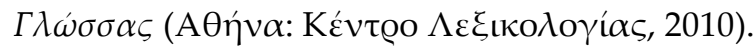

Bataille, Georges, "Hegel, Mankind and History," in Georges Bataille Essential Writings, ed. \& trans. by Michael Richardson (London: Sage Publications, 1998). Inner Experience, trans. by Stuart Kendall (Albany: SUNY Press, 2014).

The Accursed Share, Vol. I-III, trans. Robert Hurley (New York: Zone Books, 1989).

Bornedal, Peter, The Surface and the Abyss: Nietzsche as Philosopher of Mind and Knowledge (Berlin: Walter de Gruyter, 2010).

98 TSZ: The Honey Offering.

99 TSZ: The Sorcerer, 2.

100 WP: 704, KSA: 13:11[111].

(C) 2016 George Papandreopoulos http://www.kritike.org/journal/issue 18/papandreopoulos june2016.pdf ISSN 1908-7330 


\section{ON SOVEREIGNTY AND POWER}

Brusotti, Marco, “Die 'Selbstverkleinerung des Menschen' in der Moderne. Studie zu Nietzsches 'Zur Genealogie der Moral,'"' in NietzscheStudien, 21 (1992).

Burnham, D. and Jesinghausen, M., Nietzsche's Thus Spoke Zarathustra (Edinburgh: Edinburgh University Press, 2010).

Deleuze, Gilles, Nietzsche and Philosophy, trans. by Hugh Tomlinson (London: Continuum, 1986).

D'Iorio, Paolo, "Nietzsche et l'éternel retour. Genèse et interprétation", in Nietzsche. Cahiers de l'Herne (Paris: L'Herne, 2000).

Golomb, Jacob, "How to De-Nazify Nietzsche's Philosophical Anthropology," in Nietzsche, Godfather of Fascism? ed. by Robert S. Wistrich and Jacob Golomb (Princeton and Oxford: Princeton University Press, 2002).

Nietzsche's Enticing Psychology of Power (Ames: Iowa State University Press, 1989). "Will to Power: Does it Lead to the 'Coldest of All Cold Monsters'?", in The Oxford Handbook of Nietzsche, ed. by K. Gemes and J. Richardson (Oxford: Oxford University Press, 2013).

Hegel, G.W.F., Phenomenology of Spirit, trans. by A. V. Miller (Oxford and New York: Oxford University Press, 1977).

Kojeve, Alexandre, Introduction to the Reading of Hegel: Lectures on the Phenomenology of Spirit, trans. by James H. Nichols, Jr. (Ithaca and London: Cornell University Press, 1980).

Lampert, Laurence, Nietzsche's Teaching: An Interpretation of Thus Spoke Zarathustra (New Haven and London: Yale University Press, 1986).

Lange, Albert Frederick, The History of Materialism, Vol. III, trans. by E.C.T. Paul Kegan (Trench: Trübner \& Co Ltd., 1925).

Lemm, Vanessa, "Justice and Gift-Giving in Thus Spoke Zarathustra," in Luchte, James, Nietzsche's Thus Spoke Zarathustra: Before Sunrise, ed. by James Luchte (London: Continuum, 2008).

Liddell, G. H., and Scott, R., A Greek-English Lexicon (Oxford: Clarendon Press, 1996).

Mauss, Marcel, The Gift, trans. by W.D. Halls (Oxon: Routledge, 1990).

Moore, Gregory, Nietzsche, Biology and Metaphor (Cambridge: Cambridge University Press, 2002).

Nietzsche, Friedrich Wilhelm, Beyond Good and Evil, trans. by Judith Norman (Cambridge: Cambridge University Press, 2002). Abbreviated as $B G E$.

Daybreak, trans. by R.J. Hollingdale (Cambridge: Cambridge University Press, 1997). Abbreviated as $D$. Ecce Homo, trans. by Duncan Large (Oxford: Oxford University Press, 2007). Abbreviated as EH.

(c) 2016 George Papandreopoulos http://www.kritike.org/journal/issue 18/papandreopoulos june2016.pdf ISSN 1908-7330

(c) BY-NC-ND 
On the Genealogy of Morality, trans. by Maudemarie Clark and Alan J. Swensen (Indianapolis: Hackett Publishing Company Inc., 1998). Abbreviated as GM. Sämtliche Werke: Kritische Studienausgabe in 15 Einzelbänden, edited by Giorgio Colli and Mazzino Montinari (München: Deutscher Taschenbuch Verlag, 1988). Abbreviated as KSA. , The Gay Science, trans. by Josefine Nauckhoff (Cambridge: Cambridge University Press, 2001). Abbreviated as GS. The Will to Power, trans. by Walter Kaufmann and R.J. Hollingdale (New York: Vintage Books, 1968). Abbreviated as WP. Thus Spoke Zarathustra, trans. by Graham Parkes (Oxford: Oxford University Press, 2005). Abbreviated as TSZ. Twilight of the Idols, trans. by Duncan Large (Oxford: Oxford University Press, 1998). Abbreviated as TI. Untimely Meditations, trans. by R.J. Hollingdale (Cambridge: Cambridge University Press, 1997). Abbreviated as UM.

Richardson, John, Nietzsche's System (Oxford: Oxford University Press, 1996). Rosen, Stanley, The Mask of Enlightenment - Nietzsche's Zarathustra (New Haven: Yale University Press, 2004).

Small, Robin, Time and Becoming in Nietzsche's Thought (London: Continuum, 2010). 